\title{
Efeito Antimicrobiano de Óleo Essencial de Orégano em Revestimento Comestível de Hambúrguer de Frango
}

Monique Ellen Torres da Silva (I), Monique de Oliveira Maia (I), Daniele Maria Alves Teixeira Sá (I), Antônia Lucivânia de Sousa Monte (I), Marlene Nunes Damaceno (I)

(I) IFCE - Instituição Federal de Educação, Ciência e Tecnologia (Rua Estevão Remígio, 1145, Centro, Limoeiro do Norte. CEP: 62930-000)

\section{Resumo}

Pesquisas em busca de técnicas alternativas para expansão da vida de prateleira dos alimentos tem aumentado bastante na área alimentícia e impulsionado estudos sobre a utilização de conservantes naturais, como os óleos essenciais, que são considerados agentes antimicrobianos naturais. Objetivou-se com o presente estudo verificar a ação antimicrobiana do óleo essencial de orégano, com diferentes concentrações, em revestimento de hambúrgueres de frango durante o armazenamento. Foram elaborados revestimentos contendo $0,0,5$ e $1 \%(\mathrm{v} / \mathrm{v})$ de óleo essencial de orégano com base de gelatina comestível em pó sem sabor. Foi empregado um fatorial 3 ( $0 ; 0,5$ e $1 \%$ de óleo em relação a quantidade de revestimento) x $3(0 ; 7$ e 14 dias de armazenamento a $5^{\circ} \mathrm{C} \pm 2$ ), em delineamento inteiramente casualizado, com três repetições. Foram realizadas análises de Staphylococcus aureus, Coliformes a $45^{\circ} \mathrm{C}$ e Salmonella. Os resultados foram submetidos a ANOVA, teste de Tukey e análise de regressão. Os resultados demonstraram que apesar de não apresentarem diferença significativa entre si, a amostra controle (0\%) apresentou inicialmente uma contagem mínima (S. aureus, as amostras com 0 e $0,5 \%$ de óleo apresentaram contagem inicial de 7,5 x $10^{2}$, chegando a $1,5 \times 10^{6}$ e $5,9 \times$ $10^{5} \mathrm{UFC} / \mathrm{g}$ respectivamente no final do armazenamento. Já a amostra com $1 \%$ apresentou contagem inicial de $2,5 \times 10^{3}$ chegando ao $14^{\circ}$ dia com 
contagem de 3,8 x 10 , apresentando um controle maior com o aumento da concentração. Quanto a presença de Salmonella para todas as amostras foram constatadas ausência durante o armazenamento. Conclui-se que o óleo essencial de Origanum vulgare se mostra uma técnica alternativa para sistemas de conservação de alimentos, visto que foi eficaz contra coliformes termotolerantes, porém se faz necessário estudos com concentrações mais altas em temperaturas menores.

Palavras-Chave: Antimicrobiano, armazenamento, embutido cárneo Agência de Fomento: CAPES; FUNCAP 